\title{
ACRBP wt Allele
}

National Cancer Institute

\section{Source}

National Cancer Institute. ACRBP wt Allele. NCI Thesaurus. Code C51097.

Human ACRBP wild-type allele is located in the vicinity of 12 p13.31 and is approximately 9 $\mathrm{kb}$ in length. This allele, which encodes acrosin-binding protein, plays a role in proacrosin packaging and condensation for the acrosin zymogen in the acrosomal matrix. 